\title{
FAKTOR-FAKTOR YANG MEMPENGARUHI PEMANFAATAN TEKNOLOGI INFORMASI DAN PENGARUH PEMANFAATAN TEKNOLOGI INFORMASI TERHADAP KINERJA INDIVIDUAL
}

\author{
Oleh : \\ Inuk Wahyuni Istiqomah \\ (Dosen Jurusan Akuntansi STIE Al-Anwar Mojokerto)
}

\begin{abstract}
Abstrak
Tujuan Riset ini untuk menguji faktor-faktor yang mempengaruhi pemanfaatan teknologi informasi dan pengaruh pemanfaatan teknologi informasi terhadap kinerja individual dengan menguji model dari Thompson (1991) dan Goodhue dan Thompson (1995). Pengujian ini dilakukan karena adanya ketidakkonsistenan hasil Riset sebelumnya, sehingga perlu dilakukan pengujian kembali. Data yang digunakan pada Riset ini diperoleh dari persepsi individu pengguna teknologi informasi di Dinas Pendapatan Daerah Tingkat II Kabupaten dan Kota Mojokerto. Data dikumpulkan sebanyak 250 kuesioner melalui contact person. Dari jumlah tersebut yang kembali dan layak untuk dianalisis sebanyak $152(60,8 \%)$. Analisis data dilakukan dengan menggunakan teknik multivariate structural equation modelling dengan sofiware AMOS 4.01 dan SPSS 10.01. Hasil Riset menunjukkan bahwa faktor sosial, konsekuensi jangka panjang dan kondisi yang memfasilitasi berpengaruh positif tidak signifikan terhadap pemanfaatan teknologi informasi, sedangkan affect, kompleksitas, kesesuaian tugas teknologi berpengaruh negatif tidak signifikan terhadap pemanfaatan teknologi informasi. Kesesuaian tugas teknologi berpengaruh negatif tidak signifikan teehadap kinerja individual dan pemanfaatan teknologi informasi berpengaruh positif signifikan terhadap kinerja individual.
\end{abstract}

Kata-kata kunci: Faktor social, affect, kompleksitas, kesesuaian tugas teknologi, kosekuensi jangka panjang, kondisi yang memfasilitasi, pemanfaatan TI dan kinerja individual.

\section{Latar Belakang}

Beberapa dekade yang lalu, Leavitt dan Whistler (1958) telah memperkirakan bahwa Teknologi Informasi (TI) akan membawa perubahan mendasar dalam organisasi dan masyarakat. Perkiraan tersebut saat ini telah telah terbukti dalam Riset Alpar dan Kim (1990), Barua, Kriebal dan Mukhopadhyay (1995) dan Brynjolfsson dan Hitt (1996). Beberapa Riset tersebut memberikan bukti empiris bahwa investasi di bidang TI dapat memberikan kontribusi positif terhadap kinerja individual dan produktivitas perusahaan. Di samping itu, investasi pada TI mempunyai hubungan positif signifikan dengan penjualan, aktiva dan modal (Sircar, Turbonw \& Bordoloi, 2000).

Dalam bidang akuntansi, meningkatnya teknologi komputer telah mengubah pemrosesan data akuntasi secara manual menjadi secara otomatis. Otomatisasi atau sistem informasi berdasarkan pada komputer dapat melakukan berbagai fungsi secara tepat dan cepat (Daljono 1999). Pemanfaatan TI merupakan keputusan individu untuk menggunakan atau tidak menggunakan teknologi tersebut, dimana yang bersangkutan akan dipengaruhi oleh beberapa faktor yaitu : (1) faktor sosial: (2) affect; (3) kompleksitas; (4) kesesuaian-tugas teknologi; (5) konsekuensi jangka panjang;. (6) kondisi yang memfasilitasi dan (7) Ketujuh kebiasaan.

Thompson, et al (1991) menguji enam faktor yang mempengaruhi pemanfaatan personal computer $(P C)$, hasilnya terdapat hubungan positif faktor sosial, affect, 
kesesuaian tugas, konsekuensi jangka panjang, serta hubungan negatif antara kompleksitas dengan pemanfaatan PC. Faktor-faktor yang mempengaruhi pemanfaatan TI juga dikaitkan dengan kinerja baik ditingkat individual maupun di tingkat organisasi. Model tersebut dikenal dengan Technology to Performance Chain (TPC). Goodhue dan Thompson (1995), Darwin, (1999) dan Diana (2000), memberikan bukti empiris bahwa pengaruh pemanfaatan TI terhadap kinerja individual. Sebaliknya, Jurnali (2001) dan Jin. (2003) tidak membuktikan pengaruh positif pemanfaatan TI terhadap kinerja individual.

Ketidak-konsistenan hasil-hasil Riset tersebut menunjukkan masih perlu untuk dikaji ulang. Maka, riset ini dilakukan di Dinas Pendapatan Daerah Tingkat II Kabupaten dan Kota Mojokerto dengan beberapa pertimbangan. (1) TI telah dimanfaatkan secara luas di sektor publik, khususnya pada Dinas Pendapatan Daerah Tingkat II di Kabupaten dan Kota Mojokerto. (2) Riset tentang faktor-faktor yang mempengaruhi pemanfaatan TI dan pengaruh pemanfaatan TI terhadap kinerja individual di sektor publik belum pernah dilakukan. (3) adanya perbedaan karakteristik dari sektor publik dan sektor swasta.

\section{Rumusan Masalah}

Riset tentang pemanfaatan TI dan kinerja individual yang telah dilakukan di Indonesia, menunjukkan hasil yang belum konsisten, sehingga perlu dilakukan pengujian kembali. Berdasarkan uraian di atas, maka pertanyaan dalam riset ini adalah : (1) Apakah faktor sosial, affect, kompleksitas, kesesuaian-tugas teknologi, konsekuensi jangka panjang dan kondisi yang memfasilitasi berpengaruh terhadap pemanfaatan TI?; (2) Apakah kesesuaian-tugas teknologi berpengaruh terhadap kinerja individual?; (3) Apakah pemanfaatan TI berpengaruh terhadap kinerja individual?

\section{Kerangka Pemikiran}

Triandis (1971) menyatakan bahwa perilaku ditentukan oleh apa yang orangorang ingin lakukan (sikap), apa yang mereka pikirkan akan mereka lakukan (aturanaturan sosial), apa yang mereka biasa lakukan (kebiasaan) dengan konsekuensi perilaku yang mereka perkirakan. Selanjutnya, Triandis (1971), menyatakan bahwa sikap menyangkut komponen-komponen kognitif, afektif dan perilaku. Komponen kognitif menyangkut keyakinan, sedangkan komponen sikap afektif memiliki konotasi suka atau tidak suka. Triandis (1980) menyajikan suatu model perilaku interpersonal yang lebih komprehensif dengan menyatakan faktor-faktor sosial, perasaan dan konsekuensi yang dirasakan mempengaruhi tujuan perilaku dan sebaliknya akan mempengaruhi perilaku. Perilaku tidak mungkin terjadi jika situasinya (misalnya, kondisi yang memfasilitasi) tidak memungkinkan. Jadi, jika seseorang bermaksud untuk menggunakan personal computer, tetapi tidak mempunyai kemudahan atau kesempatan untuk memperolehnya, maka manfaat yang dirasakan akan berkurang.

Theory of reasoned action, menyatakan bahwa kinerja individu dari perilaku yang telah ditetapkan akan ditentukan oleh maksud dari tindakan yang akan dilakukan dan tujuan perilaku secara bersama-sama ditentukan oleh sikap individu dan normanorma subyektif. Norma subyektif diartikan sebagai persepsi seseorang bahwa kebanyakan orang adalah penting baginya untuk memperkirakan perlu atau tidaknya melakukan tindakan (Fishbein \& Ajzen, 1975). Menurut TRA sikap seseorang terhadap perilaku ditentukan oleh kepercayaan (belief) utama mengenai konsekuensi-konsekuensi dari tindakan yang dikembangkan berdasarkan konsekuensi-konsekuensi tersebut.

Technology Acceptance Model (TAM) dikembangkan oleh Davis (1989) yang bersandar pada Theory of Reasoned Action (TRA). TAM berfokus pada sikap terhadap pemakaian TI, dimana pemakai mengembangkannya berdasarkan persepsi manfaat dan kemudahan dalam penggunaan TI. Tujuan inti dari TAM adalah untuk menyediakan sebuah gambaran yang mandasar tentang pengaruh faktor-faktor eksternal terhadap kepercayaan (belief) internal, sikap dan tujuan. 
Task Technology Fit (TTF) dikembangkan oleh Goodhue dan Thompson (1995). TTF adalah tingkat dimana teknologi membantu individu dalam pelaksanaan tugastugasnya atau tugas jabatan. Secara lebih spesifik, TTF merupakan kesesuaian antara tugasnya atau tugas jabatan. Secara lebih spesidu, dan fungsi teknologi. Prioritas TTF
kebutuhan akan tugas-tugas, kemampuan individu, teknologi, dan individu.
adalah interaksi antara tugas, teknologan sebuah model yang mana

Technology to Performance Chain (TPC) merupakan sebuah model yang mana peran penting teknologi berpengaruh terhadap kinerja pada tingkat individual. Inti dari model ini adalah agar TI memberikan dampak positif terhadap kinerja individual maka teknologi tersebut harus dimanfaatkan dan teknologi tersebut harus sesuai dengan jenis pekerjaan yang dilakukan.

Thompson, et al. (1991) dengan menerapkan teori sikap dan perilaku Triandis (1980) pada konteks penggunaan PC mengemukakan bahwa pemanfaatan TI dipengaruhi oleh beberapa faktor yaitu : (1) Faktor sosial; (2) Affect; (3) Kompleksitas; (4) Kesesuaian-tugas teknologi; (5) Konsekuensi jangka panjang; (6) Kondisi yang memfasilitasi (facilitating conditions); (7) Kebiasaan (Triandis, 1971).

Kinerja (performance) didefinikasikan sebagai tingkat keberhasilan seseorang di dalam melaksanakan pekerjaannya. Dalam Risetnya Goodhue dan Thompson (1995), pencapaian kinerja individual dinyatakan dengan pencapaian serangkaian tugas-tugas individu dengan dukungan TI yang ada. Kinerja yang lebih tinggi mengandung arti terjadinya peningkatan efisiensi, efektivitas atau kualitas yang lebih tinggi, dari penyelesaian serangkaian tugas yang dibebankan kepada individu dalam organisasi.

Faktor sosial dalam suatu organisasi akan menentukan berhasil tidaknya pemanfaatan TI. Jika ada aturan-aturan yang telah ditetapkan oleh organisasi yang tidak melanggar norma, memberikan manfaat dan dapat mendukung pelaksanaan tugastugasnya, maka akan mendorong individu untuk memanfaatkan TI tersebut (Triandis 1980). Tornatzky dan Klien (1982), menemukan bahwa keseimbangan dari inovasi dengan norma-norma sosial mempunyai pengaruh signifikan pada pemanfaatan. Davis, et al (1989), menunjukkan tidak ada hubungan signifikan norma-norma sosial terhadap penggunaan PC. Sedangkan Thompson, et al., (1991) dan Qadri, (1997), menunjukkan hubungan positif faktor sosial terhadap pemanfaatan PC. Jin (2003) dan Diana (2001) menunjukkan faktor sosial berpengaruh positif signifikan terhadap pemanfaatan $\mathrm{TI}$.

Faktor sosial berpengaruh positif dan signifikan terhadap pemanfaatan $T I$.

Kondisi psikologi sangat menentukan perilaku seseorang, jika individu secara psikologi merasa senang atau gembira dengan adanya penggunaan TI di tempat kerjanya, psikologi merasa senang atau gembira dengan ad in mant dengan baik, begitu juga sebaliknya.
maka ia akan termotivasi untuk memanfaatkan TI
Kondisi psikologi ini oleh Triandis (1980) disebut sebagai faktor afeksi. Bukti empiris pengaruh pengaruh positif signifikan affect terhadap pemanfaatan $\mathrm{PC}$, Thompson, et al. (1991), Qadri (1997) dan Compeau, Christopher dan Huff, (1999). Sedangkan Jin (2003) yang memberikan bukti empiris terdapat hubungan tidak signifikan affect terhadap pemanfaatan TI. Sesuai dengan teori Triandis (1980).

$\mathrm{H}_{2}$ : Affect berpengaruh positif dan signifikan terhadap pemanfaatan TI.

Rogers dan Shoemaker (1971), menyatakan bahwa kompleksitas merupakan tingkat dimana inovasi dipersepsikan sebagai sesuatu yang relatif sulit untuk diartikan dan digunakan oleh individu. Semakin kompleks suatu inovasi, maka semakin rendah tingkat penggunaannya (Tornatzky \& Klien, 1982). Jika TI dipersepsikan dalam kontek ini, maka akan menunjukkan hubungan negatif antara kompleksitas dengan pemanfaatan TI. Hal tersebut dibuktikan oleh Riset Thompson, et al. (1991). Qadri (1997) memberikan bukti empiris kompleksitas berpengaruh positif terhadap pemanfaatan PC. Jin (2003).

$H_{3}$ : Kompleksitas berpengaruh negatif terhadap pemanfaatan $T$.

Kemampuan TI untuk meningkatkan fleksibilitas, mengubah pekerjaan atau memperoleh kesempatan kerja di masa yang akan datang yang lebih berarti bagi user, sangat menentukan pemanfaatan TI. Hal ini oleh Thompson, et al. (1991) disebut sebagai 
konsekuensi jangka panjang. Thompson, et al. (1991), Qadri, (1997) memberikan bukti empiris terdapat hubungan positif signifikan konsekuensi jangka panjang terhadap pemanfaatan PC. Sedangkan Jin (2003), menunjukkan pengaruh negatif dan signifikan antara konsekuensi jangka panjang dengan pemanfaatan TI.

$H_{+}$: Konsekuensi jangka panjang berpengaruh positif dan signifikan terhadap pemanfaatan $T I$.

Dalam konteks pemanfaatan TI, ketentuan-ketentuan yang mendukung user adalah merupakan bentuk dari kondisi yang memfasilitasi, akan mempengaruhi pemanfaatan TI. Triandis (1980) dinyatakan bahwa kondisi yang memfasilitasi merupakan faktor obyektif, yang ada dalam suatu lingkungan, dimana beberapa penilaian atau pengamatan mengakui sesuatu tindakan dapat dilakukan dengan mudah. Schultz dan Slevien, (1975) memberikan bukti bahwa kondisi yang mendukung pemanfaatan TI. Thompson, et al. (1991), Qadri (1997) menunjukkan bahwa tidak ada hubungan antara kondisi-kondisi yang memfasilitasi dengan pengunaan PC. Sedangkan Jin (2003) memberikan bukti pengaruh negatif dan lemah kondisi yang memfasilitasi terhadap pemanfaatan $\mathrm{Tl}$.

$H_{5}$ : Kondisi yang memfasilitasi berpengaruh positif dan signifikan terhadap pemanfaatan $T I$.

Tindakan individu sangat ditentukan oleh alasan yang mendasarinya, salah satu alasan untuk memanfaatkan TI adalah kesesuaian-tugas teknologi. Hal tersebut sesuai dengan TRA yang dikemukanan oleh Fishbein dan Ajzen (1975). Tornatzky dan Klien (1982) memberikan bukti bahwa sebuah inovasi akan lebih disukai untuk diadopsi jika sesuai dengan tanggung jawab pekerjaan individu yang bersangkutan. Diana (2001) memberikan bukti empiris bahwa kesesuaian-tugas teknologi tidak berpengaruh terhadap pemanfaatan $P C$, tetapi terhadap kinerja karyawan akuntansi mendukung hipotesis yang menyatakan bahwa kesesuaian-tugas teknologi mempunyai pengaruh positif terhadap kinerja karyawan akuntansi. Sedangkan Jurnali (2001), memberikan bukti empiristerdapat pengaruh positif kesesuaian tugas terhadappemanfaatan TI.

$H_{6 a}$ : Kesesuaian tugas-teknologi berpengaruh positif dan signifikan terhadap pemanfaatan $T I$.

$H_{6 b}$ : Kesesuaian tugas-teknologi berpengaruh positif dan signifikan terhadap kinerja individual

Pemanfaatan merupakan perilaku dari menggunakan teknologi dalam pekerjaan (Thompson, et al., 1991). Pengalaman dari pemanfaatan teknologi akan berpengaruh terhadap pemakai, apakah teknologi tersebut mempunyai dampak lebih baik atau lebih buruk terhadap kinerja, akan berpengaruh pada kinerja di masa yang akan datang (Goodhue \& Thompson, 1995). Goodhue dan Thompson (1995), Darwin (1999) dan Diana (2001), memberikan bukti bahwa terdapat pengaruh pemanfaatan TI terhadap kinerja Individual. Sedangkan Jurnali (2001), dan Jin (2003), memberikan bukti bahwa pemanfaatan TI tidak berpengaruh terhadap kinerja individual.

$H_{7}$ : $\quad$ Pemanfaatan TI pengaruh positif dan signifikan terhadap kinerja individual

Model kerangka pemikiran teoritis yang menggambarkan hubungan antara konstruk eksogen yaitu faktor sosial, affect, kompleksitas, kesesuaian-tugas teknologi, konsekuensi jangka panjang, dan kondisi yang memfasilitasi dengan konstruk endogen yaitu pamanfaatan TI dan kinerja individual, adalah sebagai berikut:- 


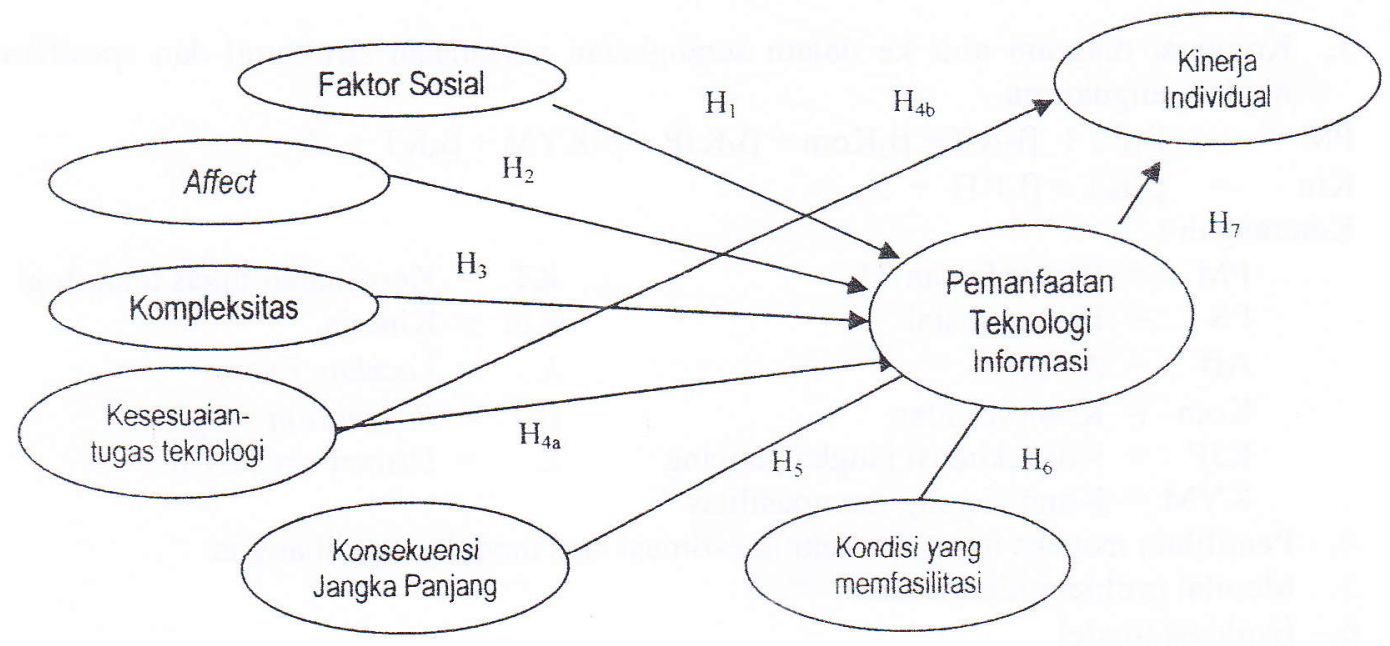

Metode Penelitian

Populasi dalam Riset ini adalah seluruh karyawan Dinas Pendapatan Daerah Tingkat II Kabupaten dan Kota Mojokerto. Sampel Riset adalah karyawan pengguna teknologi informasi di Dinas pendapatan Daerah Tingkat II Kabupaten dan Kota Mojokerto. Penentuan jumlah sampel yang akan diambil menggunakan model size, (Hair, Anderson, Tatham \& Black, 1998). Besarnya sampel yang diambil adalah 145. Metode sampling yang digunakan adalah purposive sampling.

Data dalam Riset ini dikumpulkan dengan mengantarkan langșung 250 kuesioner dengan asumsi respon rate adalah $60 \%$. Dengan didasari suatu pertimbangan bahwa kuesioner akan dikirimkan secara langsung.

Variabel eksogen dalam Riset ini terdiri dari 1) sosial faktor, pengukuran menggunakan instrumen yang dikembangkan oleh Thompson (1991) dengan lima skala likert; 2), affect, diukur dengan 5 Instrumen. Tiga instrument dikembangkan Thompson, et al. (1991) dan 2 instrumen lainnya dikembangkan Staples dan Seddon, (2004) dengan lima skala Likert; 3). kompleksitas, pengukuran mencakup 4 instrumen yang dikembangkan Thompson, et al. (1991), dengan lima skala Likert; 4) kesesuaian-tugas teknologi, pengukuran mencakup 6 pertanyaan yang kembangkan Goodhue dan Thompson (1995) dengan 5 skala Likert; 5) konsekuensi, pengukuran mencakup 6 pertanyaan yang dikembangkan Thompson, et al. (1991), dengan lima skala likert dan 6) jangka panjang dan kondisi yang memfasilitasi, pengukuran mencakup 4 pertanyaan yang kembangkan Thompson, et al. (1991), dengan lima skala likert.

Variabel endogen terdiri dari 1) pemanfaatan teknologi informasi pengukuran mencakup lima instrumen, sebanyak 3 instrument dikembangkan Thompson et al (1991) dan 2 instrument dikembangkan Staples dan Seddon, (2004), dengan skala kategori, dan; 2) kinerja individual, Pengukuran konstruk menggunakan 5 instrumen, 3 instrument Goodhue dan Thompson (1995) sedangkan, 2 instrumen dikembangkan Staples dan Seddon, (2004), dengan lima skala Likert.

Pengujian hipotesis dilakukan dengan menggunakan Structural Equation Model dengan pertimbangan bahwa SEM memiliki kemampuan untuk menggabungkan measurement model dengan structural model secara simultan dan efisien bila dibandingkan dengan teknik multivariat lainnya (Hair, et al., 1998). Penggunaan model persamaan tersebut dengan aplikasi Analysis of Momen Structure (AMOS 4.01) Hair, et al. (1998) mengemukakan tujuh langkah dalam pemodelan yang digunakan seperti:

1. Mengembangkan model berdasarkan teori

2. Pengunaan diagram alur untuk menunjukkan hubungan kausalitas 
3. Konversi diagram alur ke dalam serangkaian persamaan struktural dan spesifikasi model pengukuran.

$$
\begin{array}{rlrl}
\mathrm{PM} & =\beta_{1} \mathrm{FS}+\beta_{2} \mathrm{Aff}+\beta_{3} \mathrm{Kom}+\beta_{4} \mathrm{KJP}+\beta_{5} \mathrm{KYM}+\beta_{6} \mathrm{KT}+\mathrm{Z}_{1} \\
\mathrm{Kin} & =\beta_{6} \mathrm{KT}+\beta_{7} \mathrm{PTI}+\mathrm{Z}_{2} & & \\
\text { Keterangan : } & \mathrm{KT}=\text { Kesesuaian-tugas teknologi } \\
\text { PM } & =\text { Pemanfaatan TI } & \mathrm{Kin}=\text { Kinerja } \\
\mathrm{FS} & =\text { Faktor sosial } & \lambda=\text { Loading factor } \\
\text { Aff } & =\text { Affect } & \beta & =\text { Regression weight } \\
\text { Kom } & =\text { Kompleksitas } & \mathrm{Z} & =\text { Disturbance term } \\
\text { KJP } & =\text { Konsekuensi jangka panjang } & \mathrm{Z} &
\end{array}
$$

4. Pemilihan matriks input dan teknik estimasi atas model yang dibangun

5. Menilai problem identifikasi

6. Evaluasi model

7. Interpretasi dan modifikasi model.

\section{Masil Penelitian}

Dari pengiriman kuesioner sebanyak 250 eksemplar, yang kembali dan layak untuk dianalisis sebanyak 152 kuesioner dengan tingkat respon rate sebesar $60,8 \%$.

\section{Gambaran Umum Responden}

Gambaran umum 152 orang responden yang berpartisipasi menunjukkan bahwa sebagian besar responden berjenis kelamin pria sebanyak 99 orang $(65 \%)$ dengan usia berkisar antara 31 - 40 tahun sebanyak 63 orang (41\%) dan memiliki masa kerja selama > 5 tahun 126 orang (83\%). Mayoritas tingkat pendidikan responden S1 sebanyak 96 orang $(63 \%)$ dan latar belakang pemanfaatan teknologi informasi 44 orang (29\%) pernah mengikuti kursus komputer, pelatihan, dan hobi menggunakan teknologi informasi.

\section{Uji Non Response Bias}

Berdasarkan hasil output tersebut diketahui bahwa besarnya $t$ hitung adalah 1,236 dengan probabilitas 0,218 . Karena probabilitas $>0,05$, maka $\mathrm{H}_{0}$ tidak dapat ditolak atau menunjukkan bahwa tidak ada perbedaan score antara kelompok kuesioner yang kembali dan yang tidak kembali.

\section{Pengujian Hipotesis dan Pembahasan}

\section{Measurement Model dengan Confirmatory Factor Analysis}

Hasil statistik overall model fit untuk faktor sosial, affect, kompleksitas, kesesuaian tugas teknologi, konsekuensi jangka panjang, kondisi yang memfasilitasi, pemanfaatan TI dan kinerja individual memiliki tingkat kesesuaian yang baik, sehingga model pengukuran tersebut dapat diterima dengan baik. Hasil analisis loading factor dari konstruk menunjukkan nilai $C R$ berada di atas ambang batas 1,96 (pada taraf signifikansi 0,05 ), sehingga observed variables tersebut secara signifikan merupakan indikator dari variabel tersebut. Nilai loading $>2$ kali $S E$ menunjukkan convergen validity telah terpenuhi. Semua variabel telah melampaui batas yang direkomendasikan yaitu di atas atas 0,70 untuk composite reliability dan di atas 0,50 untuk average variance extracted, kecuali variabel kompleksitas dan kesesuaian tugas teknologi average variance extracted dibawah yang direkomendasikan. Karena composite reliability telah memenuhi syarat, maka reliabilitas untuk kompleksitas dapat diterima.

\section{Evaluasi Asumsi SEM}

\section{Evaluasi Normalitas Data}

Hasil statistik menunjukkan bahwa nilai critical ratio skewness dan kurtosis dari semua indikator berdistribusi normal karena nilainya berada diantara $\pm 2,58$. Sedangkan normalitas multivariate berada diantara $\pm 2,58$, sehingga dapat disimpulkan bahwa secara keseluruhan asumsi normalitas terpenuhi. 


\section{Evaluasi Outlier}

Hasil uji statistik menunjukkan bahwa nilai z-score memiliki rata-rata sama dengan nol dengan standar deviasi sebesar 1 dan tidak ditemukan nilai z-score yang lebih besar dari $\pm 3,0$ maka disimpulkan tidak terdapat univariate outlier pada data yang dianalisis. Multivariate outlier dideteksi dengan nilai mahalanobis distance untuk tiap observasi dapat dihitung dan akan menunjukkan jarak sebuah observasi dari rata-rata semua variabel dalam sebuah ruang multidimensional (Hair et al, 1998). Hasil output AMOS 4.01 menunjukkan tidak ada kasus yang memiliki mahalanobis distance lebih besar dari $\chi^{2}(642 ; 0,05)=702,055$ maupun $\chi^{2}(642 ; 0,01)=728,289$, sehingga disimpulkan tidak terdapat kasus multivariate outlier pada responden yang berpartisipasi. Evaluasi Multicollinearity atau Singularity

Hasil output AMOS 4.01. menunjukkan nilai determinant of sample covariance matrix sebesar $1,8510 \mathrm{e}-013$. Nilai tersebut berada di atas nol dan tidak ada warning dari program yang menunjukkan tidak adanya masalah multicollinearity atau singularity.

Analisis Full Structural Equation Modelling (SEM)

Hasil pengujian atas full structural equation model menunjukkan nilai kesesuaian yang baik untuk dapat menerima model Riset yang diajukan, sehingga model pengukuran untuk faktor-faktor yang mempengaruhi pemanfaatan TI dan pengaruh pemanfaatan TI terhadap kinerja Individual dapat diterima dan dapat digunakan untuk mengkonfirmasi hasil antara kesesuaian teoritis dan pengujian secara empiris.

Pengujian Korelasi

Korelasi antara konstruk eksogen Riset ini menunjukkan bahwa masingmasing konstruk eksogen memilikki korelasi yang relatif kecil, sehingga disimpulkan bahwa masing-masing konstruk eksogen tidak saling berkorelasi satu sama lainnya.

\section{Pengujian Hipotesis dan pembahasan}

Pengujian Hipotesis 1 : Faktor Sosial Berpengaruh Positif dan Signifikan Terhadap Pemanfaatan Teknologi Informasi

Hasil statistik menunjukkan nilai C.R. 0,710 dengan nilai standardized regression weight 0,068 , di samping itu nilai $p=0,477$ juga berada di atas nilai signifikansi 0,05 maupun 0,01 . Sehingga disimpulkan bahwa faktor sosial berpengaruh positif dan tidak signifikan terhadap pemanfaatan teknologi informasi. Hasil ini gagal menerima hipotesis 1, yang berarti bahwa eksistensi faktor sosial dalam mempengaruhi tingkat pemanfaatan teknologi informasi di Dinas Pendapatan Daerah Tingkat II Kabupaten dan Kota Mojokerto sangat lemah. Dukungan dari rekan sekerja, pimpinan kantor, atasan, dan organisasi terhadap pemanfaatan teknologi informasi belum mampu meningkatkan intensitas dan frekuensi penggunaan teknologi informasi. Dukungan dari lingkungan sosial tersebut belum mampu meningkatkan banyaknya jenis software yang dikuasai pengguna dalam menyelesaikan tugas-tugas rutinnya.

\section{Pengujian Hipotesis 2 : Affect Berpengaruh Positif dan Signifikan Terhadap} Pemanfaatan Teknologi Informasi

Uji statistik menunjukkan nilai C.R. $-0,900$ dengan nilai standardized regression weight negatif $-0,085$. Nilai C.R., sehingga disimpulkan bahwa affect berpengaruh negatif dan tidak signifikan terhadap pemanfaatan teknologi informasi. Hasil ini gagal menerima hipotesis 2, yang berarti bahwa meski secara psikologis seorang individu merasa senang menggunakan teknologi informasi, dan tidak membuatnya frustasi, individu tersebut tidak merasa bosan jika bekerja dengan menggunakan komputer, namun hal tersebut belum mampu meningkatkan intensitas dan frekuensi penggunaan maupun jenis software yang dikuasainya. Berdasarkan kuesioner, diketahui bahwa perasaan senang dalam menggunakan teknologi informasi baru mampu membawa pegawai untuk menggunakan teknologi informasi dengan intensitas rata-rata 90-105 menit dalam sehari, 
sedangkan frekuensi penggunaannya rata-rata hanya sekali dalam sehari. Perbedaan hasil Riset ini dengan Riset sebelumnya disebabkan karena lingkungan kerja responden yang berbeda. Kurang memadainya prasarana yang mendukung pemanfaatan teknologi informasi menyebabkan mereka tidak termotivasi untuk meningkatkan intensitas atau frekuensi pemakaian maupun meningkatkan jenis software yang dikuasainya, meski secara psikologis mereka senang menggunakan teknologi informasi.

Pengujian Hipotesis 3 : Kompleksitas Berpeagaruh Negatif dan Signifikan Terhadap Pemanfaatan Teknologi Informasi

Statistik nilai nilai C.R. -1,143 dengan nilai standardized regression weight negatif $-0,133$. Sehingga disimpulkan bahwa kompleksitas berpengaruh negatif dan tidak signifikan terhadap pemanfaatan teknologi informasi. Hasil ini gagal untuk menerima hipotesis 3, itu berarti bahwa Riset ini mendukung Tornatzky dan Klien (1982) yang menyatakan bahwa semakin kompleks suatu inovasi, maka semakin rendah penggunaannya. Pernyataan Tomatzky dan Klien (1982) serta Rogers dan Shoemaker (1971) juga berlaku di Dinas Pendapatan Daerah Tingkat II Kabupaten dan Kota Mojokerto. Semakin rumit teknologi informasi semakin rendah intensitas atau frekuensi penggunaannya. Pengaruh negatif yang sangat lemah dalam Riset ini mendukung hasil Riset Jin (2003), sedangkan Thompson et al (1991) memberikan bukti empiris bahwa terdapat hubungan negatif antara kompleksitas dengan pemanfaatan personal computer.

Pengujian Hipotesis 4 : Konsekuensi Jangka Panjang Berpengaruh Positif dan Signifikan Terhadap Pemanfaatan Teknologi Informasi

Nilai C.R. 1,674 dengan nilai standardized regression weight positif 0,169 . Nilai C.R $1.674<$ nilai kritis1,96. Sehingga disimpulkan bahwa konsekuensi jangka panjang berpengaruh positif dan tidak signifikan terhadap pemanfaatan teknologi informasi. Hasil uji statistik tersebut gagal untuk menerima hipotesis 4 , yang memberikan gambaran bahwa responden di Dinas Pendapatan Daerah Tingkat II Kabupaten dan Kota Mojokerto belum meyakini manfaat dari pemanfaatan teknologi informasi sehingga konsekuensi jangka panjang tersebut belum mampu meningkatkan intensitas atau frekuensi penggunaan teknologi informasi maupun jenis software yang dikuasainya. Pengujian hipotesis 4 memberikan hasil yang berbeda dengan Riset-Riset sebelumnya. Thompson et al (1991), Jin (2003) Qadri (1997) dan Diana (2003) memberikan bukti empiris bahwa konsekuensi jangka panjang pengaruh yang positif dan signifikan terhadap pemanfaatan teknologi informasi.

Pengujian Hipotesis 5 : Kondisi yang memfasilitasi Berpengaruh Positif dan Signifikan Terhadap Pemanfaatan Teknologi Informasi

Hasil statistik dari nilai C.R. 1,822 dengan nilai standardized regression weight 0,185 . Sehingga disimpulkan bahwa kondisi yang memfasilitasi berpengaruh positif dan tidak signifikan terhadap pemanfaatan teknologi informasi. Hasil tersebut gagal menerima hipotesis 5, yang berarti bahwa tersedianya panduan dalam memilih dan menggunakan hardware dan soffware, tersedianya bantuan jika pengguna menemukan kesulitan yang berhubungan dengan hardware dan software belum mampu memperbaiki tingkat pemanfaatan teknologi informasi di Dinas Pendapatan Daerah Tingkat II Kabupaten dan Kota Mojokerto. Thompson et al (1991) dan Qadri (1997) menemukan hubungan negatif dan tidak signifikan antara kondisi yang memfasilitasi dengan pemanfaatan teknologi informasi.

Pengujian Hipotesis 6a : Kesesuaian Tugas Teknologi Berpengaruh Positif dan Signifikan Terhadap Pemanfaatan Teknologi Informasi

Statistik dari nilai C.R. -1,293 dengan nilai standardized regression weight negatif $-0,157$. Sehingga disimpulkan bahwa kesesuaian tugas teknologi berpengaruh negatif dan tidak signifikan terhadap pemanfaatan teknologi informasi. Hasil tersebut gagal untuk menerima hipotesis 6a. Hal ini mengambarkan bahwa meskipun disadari oleh para pengguna teknologi informasi di Dinas Pendapatan Daerah Tingkat II Kabupaten 
dan Kota Mojokerto, pemanfaatan teknologi informasi dapat mendukung tanggung jawab pekerjaan individu yang bersangkutan, namun hal tersebut belum dapat memotivasi untuk memanfaatkan teknologi informasi pada tingkat yang maksimal. Meskipun menggunakan teknologi informasi dapat meringankan tugas-tugas pemakainya, namun hal tersebut sering kali tidak dianggap sebagai bentuk reward. Hal inilah yang menyebabkan tingkat pemanfaatan teknologi informasi di Dinas Pendapatan Daerah Tingkat II Kabupaten dan Kota Mojokerto ditinjau dari intensitas atau frekuensi penggunaan maupun jenis software yang dikuasai para penggunanya tidak dapat maksimal. Hasil pengujian ini mendukung Riset Jin (2003) yang menemukan hubungan negatif dan tidak signifikan kesesuaian teknologi terhadap pemanfaatan teknologi informasi.

Pengujian Hipotesis 6b: Kesesuaian Tugas Teknologi Berpengaruh Positif dan Signifikan Terhadap Kinerja Individual

Nilai C.R. $-1,115$ dengan nilai standardized regression weight negatif $-0,103$. Sehingga disimpulkan bahwa kesesuaian tugas teknologi berpengaruh negatif dan tidak signifikan terhadap kinerja individual. Hasil tersebut gagal menerima hipotesis $6 \mathrm{~b}$. Hal ini menunjukkan bahwa kesesuaian tugas teknologi di lingkungan Dinas Pendapatan Daerah Tingkat II Kabupaten dan Kota Mojokerto belum mampu memperbaiki atau meningkatkan kinerja individual. Hal ini dapat dimaklumi karena kinerja di lingkungan Pemerintah Daerah memang sangat sulit untuk ditingkatkan. Hasil Riset ini bertentangan dengan hasil Riset Diana (2003). Diana (2003) menemukan hubungan yang positif dan signifikan antara kesesuaian tugas teknologi dengan kinerja individual.

Pengujian Hipotesis 7 : Pemanfaatan Teknologi Informasi Berpengaruh Positif dan Signifikan Terhadap Kinerja Individual

Nilai C.R. 2,237 dengan nilai standardized regression weight positif 0,212 . Sehingga dapat disimpulkan bahwa pemanfaatan teknologi informasi berpengaruh positif dan signifikan terhadap kinerja individual pada tingkat signifikansi 0,05 tetapi tidak signifikan pada tingkat signifikansi 0,01 . Hasil tersebut gagal untuk menolak hipotesis 7 . Hal ini menunjukkan bahwa tingkat pemanfaatan teknologi informasi di lingkungan Dinas Pendapatan Daerah Tingkat II Kabupaten dan Kota Mojokerto ditinjau dari intensitas atau frekuensi penggunaan dan jenis software yang dikuasai oleh pengguna memiliki pengaruh yang positif dalam memperbaiki atau meningkatkan kinerja individual. Pengaruh ini membawa perubahan yang signifikan terhadap kinerja individual di lingkungan Dinas Pendapatan Daerah Tingkat II Kabupaten dan Kota Mojokerto.

\section{Analisis Pengaruh Langsung dan Tidak Langsung}

Hasil statistik menunjukkan terdapat pengaruh langsung yang positif lemah dari kondisi yang memfasilitasi sebesar 0,185, konsekuensi jangka panjang sebesar 0,169 dan faktor sosial sebesar 0,068 terhadap pemanfaatan teknologi informasi. Pengaruh langsung yang bersifat negatif lemah terhadap pemanfaatan teknologi informasi ditunjukkan oleh kesesuaian tugas teknologi sebesar -0,157, kompleksitas sebesar -0,133, dan affect sebesar $-0,085$, ini berarti bahwa pemanfaatan teknologi informasi berpengaruh secara langsung terhadap kinerja individual dengan nilai positif sebesar 0,212 . Sedangkan kesesuaian tugas teknologi berpengaruh secara langsung terhadap kinerja individual sebesar $-0,068$. Hal ini menunjukkan bahwa pengaruh tidak langsung kesesuaian tugas teknologi terhadap kinerja individual melalui pemanfaatan teknologi informasi sebesar 0,033. Nilai ini lebih kecil jika dibandingkan dengan nilai pengaruh langsungnya sebesar $-0,103$. Sehingga, kesesuaian tugas teknologi akan memilikki pengaruh yang lebih robust (kuat) terhadap kinerja individual jika pengaruh tersebut bersifat langsung daripada jika pengaruh tersebut bersifat tidak langsung dengan pemanfaatan teknologi informasi sebagai variabel mediasi. Pemanfaatan teknologi informasi sebagai variabel mediasi 
(intervening) akan memperlemah pengaruh kesesuaian tugas teknologi terhadap kinerja individual. Pengaruh tidak langsung kompleksitas dan affect terhadap kinerja individual melalui pemanfaatan teknologi informasi yaitu masing-masing sebesar $-0,028$ dan $-0,018$. Sedangkan, pengaruh tidak langsung kondisi yang memfasilitasi, konsekuensi jangka panjang dan faktor sosial terhadap kinerja individual melalui pemanfaatan teknologi informasi bersifat positif lemah masing-masing sebesar $0,039,0,036$ dan 0,015 . Pengaruh total kondisi yang memfasilitasi, konsekuensi jangka panjang, kesesuaian tugas teknologi, kompleksitas, affect dan faktor sosial terhadap pemanfaatan teknologi informasi menunjukkan nilai sebesar pengaruh langsungnya karena tidak ada pengaruh lain yang mempengaruhi kekuatan tiap hubungan tersebut. Pengaruh total kondisi yang memfasilitasi, konsekuensi jangka panjang, kompleksitas, affect, dan faktor sosial, terhadap kinerja individual menunjukkan nilai sebesar nilai pengaruh tidak langsungnya. Pengaruh total pemanfaatan teknologi informasi terhadap kinerja individual menunjukkan nilai sebesar pengaruh langsungnya yaitu 0,212 . Sedangkan pengaruh total kesesuaian tugas terhadap kinerja individual menunjukkan nilai -0,136 yang merupakan penjurnlahan pengaruh langsung sebesar $-0,103$ dan pengaruh tidak langsungnya sebesar $-0,033$.

\section{Simpulan}

Hasil Riset ini memberikan bukti empiris bahwa faktor sosial berpengaruh secara positif dan tidak signifikan terhadap pemanfaatan teknologi informasi, yang beranti bahwa dukungan dari rekan sekerja, pimpinan kantor, atasan, atau organisasi terhadap pemanfaatan teknologi informasi belum mampu meningkatkan intensitas dan frekuensi penggunaan teknologi informasi dan juga belum mampu meningkatkan jenis-jenis software yang dikuasai pengguna dalam menyelesaikan tugas-tugas rutinnya. Affect memiliki pengaruh negatif dan tidak signifikan terhadap pemanfaatan teknologi informasi, disimpulkan bahwa meski secara psikologis seorang individu merasa senang menggunakan teknologi informasi, menggunakan teknologi informasi tidak membuatnya frustasi, dan individu tersebut tidak merasa bosan jika bekerja dengan menggunakan komputer, namun hal tersebut belum mampu meningkatkan intensitas, frekuensi penggunaan maupun jenis software yang dikuasainya. Kompleksitas berpengaruh negatif dan tidak signifikan terhadap pemanfaatan teknologi informasi. Hal ini memberikan gambaran bahwa responden Riset di Dinas Pendapatan Daerah Tingkat II Kabupaten dan Kota Mojokerto belum meyakini manfaat yang akan diperoleh dari pemanfaatan teknologi informasi sehingga konsekuensi jangka panjang tersebut belum mampu meningkatkan intensitas atau frekuensi penggunaan teknologi informasi maupun jenis software yang dikuasainya.

Kondisi yang memfasilitasi berpengaruh positif dan tidak signifikan terhadap pemanfaatan teknologi informasi. Hal ini menunjukkan bahwa tersedianya panduan dalam memilih dan menggunakan hardware dan software, tersedianya bantuan jika pengguna menemukan kesulitan yang berhubungan dengan hardware dan software, belum mampu memperbaiki tingkat pemanfaatan teknologi informasi di Dinas Pendapatan Daerah Tingkat II Kabupaten dan Kota Mojokerto. Kesesuaian tugas teknologi berpengaruh negatif dan tidak signifikan terhadap pemanfaatan teknologi informasi. Hal ini menunjukkan bahwa meskipun disadari pemanfaatan teknologi informasi dapat mendukung tanggung jawab pekerjaan individu yang bersangkutan, namun hal tersebut belum dapat memotivasi untuk memanfaatkan teknologi informasi pada tingkat yang maksimal. Kesesuaian tugas teknologi berpengaruh negatif dan tidak signifikan terhadap pemanfaatan teknologi informasi. Hasil ini menunjukkan bahwa kesesuaian tugas teknologi di lingkungan Dinas Pendapatan Daerah Tingkat II Kabupaten dan Kota Mojokerto belum mampu memperbaiki atau meningkatkan kinerja individual. Pemanfaatan teknologi informasi berpengaruh positif dan signifikan terhadap kinerja individual pada tingkat signifikansi 0,05 . Hasil pengujian ini menunjukkan bahwa 
tingkat pemanfaatan teknologi informasi di lingkungan Dinas Pendapatan Daerah Tingkat II Kabupaten dan Kota Mojokerto ditinjau dari intensitas atau frekuensi penggunaan dan jenis software yang dikuasai oleh pengguna memilikki pengaruh yang positif dalam memperbaiki atau meningkatkan kinerja individual. Hal tersebut selanjutnya membawa perubahan yang signifikan terhadap kinerja individual di lingkungan Dinas Pendapatan Daerah Tingkat II Kabupaten dan Kota Mojokerto.

\section{Keterbatasan}

Riset ini memiliki keterbatasan-keterbatasan yang dapat mengganggu hasil Riset. Riset ini hanya mengambil satu obyek Riset sektor publik yaitu Dinas Pendapatan Daerah Tingkat II Kabupaten dan Kota Mojokerto. Hal tersebut memberikan kemungkinan akan mengurangi kemampuan generalisasi temuan Riset ini. Keterbatasan lain dalam Riset ini dikarenakan pengukuran seluruh variabel yang digunakan dalam Riset ini bersifat subyektif atau berdasarkan persepsi responden, sehingga dapat menimbulkan masalah jika persepsi responden berbeda dengan keaadaan sesungguhnya

Daftar Pustaka

Alpar, P., dan Kim, M.A., (1990), "A Microeconomic Approach to the Measurement of Information Technology Value" Jurnal of Management Information System, pp. 55-66

Arbuckle, J.L. and Wothke, W. 1999. "AMOS User's Guide". SmallWaters Corporation. Chicago.

Bagozzi, R.P. and Baumgartner, H. 1994. "The Evaluation of Structural Equation Models and Hypothesis Testing" in R.P. Bagozzi(Ed), Principles Of Marketing Research, Oxford, England : Blackwell, 1994, pp. 386-422.

Barua, A.: Kriebel, C.H.; dan Mukhopadhyay, T., (1995), "Information Technology and business value: an Analytic and empirical investigation", Information System Research, March, pp.3-23.

Brynjolfsson, E., dan Hitt, L., (1996), "Paradox lost Firm-level evidence on the returns of information systems", Management Science, pp541-558.

Compeau, Deborah: Higgins, Christopher A.: Sid Huff, (1999) "Social Cognitive Theory and Individual Reactions to Computing Technology: A Longitudinal Study", MIS Quarterly, June, pp.145-158

Daljono, 1999, Pengaruh Teknologi Yang Diterapkan Pada system Informasi Terhadap Kinerja Karyawan Perusahaan, $M E B$, Vol. XI. No. 1-2.

Darwin, R, N, (1999), Komputerisasi Pasar Swalayan: Implikasi Terhadap Kinerja Karyawan. Tesis Program Pascasarjana Magister Manajemen Universitas Diponegoro (tidak dipublikasikan)

Davis, Fre D., (1989), "Perceived Usefulness, Perceived Ease of Use, and User Acceptance of Information Technology", MIS Quarterly, September, pp.319340

Davis, Fred D.: Bagozzi, Richard P.: dan Warshaw, Paul R., (1989), "User Acceptance Of Computer Technology: A Comparison Two Theoretical Models," Management Science, August, pp.982-1003

Diana P. Medah, (2001), "Studi Empiris Tentang Faktor-Faktor yang Mempengaruhi Pemanfaatan Personal Computing dan Dampaknya Terhadap Kinerja Karyawan Akuntansi, Thesis-S2 UNDIP.

Ferdinand, Agusty, (2000), Structural Equation Modeling Dalam Riset Manajemen, Badan Penerbit Universitas Diponegoro.

Fishbein, M. dan Ajzen, I., (1975), "Belief, Attitude, Intentions and Behavior: An Introduction to Theory and Research," Addison-Wesely, Boston, MA. 
Gerbing, D.W. and Anderson, J.C. 1988. "Monte Carlo Evaluation of Goodness-of-Fit Indices for Structural Equation Models", in K.A. Bollen and J.S. Long (Eds), Testing Structural Equation Models". Newbury Park. California : Senge, 1993, pp. $40-65$.

Ghozali, Imam., (2004) "Model Persamaan Struktural" Badan Penerbit Universitas Diponegoro.

Goodhue, Dela L, dan Thompson, Ronald L., (1995), "Task-Technology Fit and Individual Performance", MIS Quarterly, June pp 1827-1844

Gudono dan Mardiyah. 2001. "Pengaruh Ketidakpastian Lingkungan dan Desentralisasi Terhadap Karakteristik Sistem Akuntansi Manajemen". Jurnal Riset Akuntansi Indonesia. Vol. 15 No. 1, h. $1-27$.

Hair, Joseph F., Jr.; Andrson, Roplph E.: Tatham, Ronald L., dan Black, William C., (1998), Multivariate Dana Analysis, $5^{\text {th }}$ Edition, Upper Saddle Rive, New Jersey, Prentice-Hall International Inc.

Jumali, Teddy (2001), "Analisis pengaruh Faktor kesesuaian-tugas teknologi dan pemanfaatan teknologi informasi terhadap kinerja akuntan publik, Simposium Nasional Akuntansi IV.

Leavitt, Harold J. dan Whister, Thomas L., (1958), "Management in the 1980's" Harvad Business Review, Nopmeber-Desember

Qadri, Rahmi, (1997), "Pengaruh faktor sosial, affect, konsekuensi yang dirasakan dan facilitating condition terhadap pemanfaatan komputer", Tesis S-2 UGM.

Rogers, E.M and Shoemaker, F.F., (1971), Comminication of Innovations: A CrossCultural Approach, Fee Press, New York, NY

Schultz, R.L., dan Slevien D.P., (1975), "Implementation and Organizational Validity: An Empirical Investigation", In Implementing Operation Research' Management Science. New York pp.163-182.

Sircar, Sumit; Turbonw, Joe L., and Bordoloi, Bijov, (2000), "A Framework for Assessing the Relationship Between Information Technology Investments and Firm Performance", Journal of Monagement Information Systems, Spring, 6967.

Staples, Sandy D. dan Seddon, 2004, "Testing the Technology-To-Performance Chain Model", Journal of Organizational and End User Computing, Oct-Dec. ppl735.

Tabachnick, B.G. and Fidell, L.S. 1996. "Using Multivariate Statistics Third Edition". Harper Collins College Publishers. New York.

Tjhai Fung Jin, 2003, Analisis Faktor-faktor yang mempengaruhi Pemanfaatan Teknologi Informasi dan Pengaruh Pemanfaatan Teknologi Informasi Terhadap Kinerja Akuntan Publik, Jurnal Bisnis dan Akuntansi, Vol 5, No. 1, April

Thompson, Ronald L., Higgins, Christoper A., dan Howell, Jane M., (1991), "Personal Computing: Toward a Conceptual Model of Utilization", MIS Quarterly, March, pp.125-143.

Tornatzky, L.G. dan Klien, K.J., (1982), "Innovation Characteristics and Innovation Adoption-Implementation: A Meta Analysis of Findings," IEEE Transaction on Engineering Management, Februari, pp.28-45.

Triandis, H.C., (1971), "Attitudes and Attitudes Change", Jhon Weley and Sons, Inc, New York.

Triandis, H.C., (1980), "Value, Attitudes and Interpersonal Behavior," University of Nabraska Press, Lincoln, NE, pp.195-259. 